AGRARIS: Journal of Agribusiness and Rural Development Research

Vol. 7 No. 1 January - June 2021,

Pages: $91-110$

Article history:

Submitted: December $10^{\text {th }}, 2020$

Accepted: April $11^{\text {th }}, 2021$
Nurliza*, Anita Suharyani, Aditya Nugraha

Department of Agribusiness, Faculty of Agriculture, University of

Tanjungpura, Jl. Prof. Hadari Nawawi, Pontianak, Indonesia

*)Correspondence email: nurliza.spmm@gmail.com

\title{
The Product Features, Functions, and Benefits of Seafood Products for Competitive Repositioning
}

\author{
DOI: https://doi.org/10.18196/agraris.v7i1.10571
}

\begin{abstract}
The global demand for seafood products increased in a dynamic environment. Still, fails to achieve competitive positioning due to labeling, unattractive and unprofitable targeted segments, and less preferred quality and features. Thus, this study tried to create competitive positioning through features, functions, and benefits of seafood product attributes. The results arranged through consumer characteristics, consumer preference with conjoint analysis, market identification and competition with regression analysis, Multidimensional Scaling, and Correspondence Analysis from 206 respondents. The results prove that (i) canned fish, dried fish, and salted fish competed on freshness, durability, and food safety (labels); (ii) shredded fish, surimi, and pedak competed on density, taste, physiological function, and easy-to-use feature; (iii) crackers competed on taste, social function, and psychological function; (iv) shrimp paste competed on shape, color, surface condition, texture, additive content, and chemicals. The implications of the results: (i) transported and packed to processing plants and food storage facilities; (ii) an increase in food diversity, food fortification, and supplementation; (iii) cultural congruence between the product and the market with certain packaging designs, launch timing, and advertising; (iv) several methods of process, such as quick freezing and cookchilling, pasteurized before packed or retort pouch and natural food additives.
\end{abstract}

Keywords: competitive positioning, product features, product functions, product benefits, perceptual map.

\section{INTRODUCTION}

Recently, the seafood product demand rate is increasing globally (OECD-FAO, 2018) due to the ease of information exchange. Their markets become a key driver of transition toward more sustainable and responsible seafood production globally (The David and Lucile Packard Foundation, 2017). Meanwhile, dynamic competitive environment and rapid changes in consumer needs (D’Aveni, 1998; Hunt \& Arnett, 2004) cause a tremendous challenge. Careful consideration should be given for seafood products with an assessment of the current market situation by analyzing the external threats and opportunities as well as internal strengths and weaknesses for effective marketing strategies (Engle, Quagrainie, \& Dey, 2016).

In product-specific marketing strategies, product positioning needs a distinctive image of target consumers' minds related to their buying decisions (Ostasevičiute \& Šliburyte, 2008). The 
successful positioning will convey why one company's product is preferred than other companies' by wielding competitive perspective, clear mind, consumer perception, uniqueness, and competitive advantage (Saqib, 2019). It will ensure that the marketing messages are received well by the target consumers through the right communication channels (Richards, 2015).

However, the current seafood product marketing in empirical literatures is indicated failing in achieving competitive positioning of seafood products because of some reasons, such as labeling (Alfnes, Chen, \& Rickertsen, 2018), unattractive and unprofitable targeted segments, less preferred quality and features, uncompetitive price, short-term orientation, and poor procedure organization (FAO, 2013). In this case, product attributes and consumer segments play an important role in the buying decision of seafood products (Olsen, Tuu, \& Grunert, 2017).

Despite the importance of the positioning of seafood products for effective marketing strategies, strengths and weaknesses of different products' attributes only receive little attention. In fact, product quality is competing simultaneously in consumer perception. Understanding regarding this can be obtained by linking customer perception and quality dimensions for developing competitive positioning in marketing strategy.

Therefore, careful consideration should be given for the seafood products with an assessment on the current market situation with the analysis of internal strengths and weaknesses of the product attributes based on the quality dimension theory (Garvin, 1987) by taking into account what attributes characterize the quality of both the competitive firms and consumer satisfaction. Thus, this study gives a better understanding of how consumers create their perceptions about products through a combination of features, functions, and benefits of seafood products in the market for designing a competitive positioning.

\section{RESEARCH METHOD}

This study was conducted by involving 206 participants who often consumed seafood products on many occasions. The participants were from coastal areas and the main producers of seafood products in West Kalimantan, Indonesia. Data were obtained through interviews and questionnaires, which considerably had a high return rate and needed fewer answers, with controlled answering order, and were practical and relatively flexible (Alshenqeeti, 2014). The study also used in-depth information about external behavior and internal beliefs regarding seafood products to obtain richer data and validate the research findings (Ingleby, 2012; Alshenqeeti, 2014; Cohen et al., 2017).

The competitive positioning of seafood products was arranged based on the value attributes through three steps. The first step was identification of consumer characteristics (i.e. age, religion, ethnicity, family members, education, job-status, time of purchase, and expenditure) to ensure that the collected data strictly describe the target data (Alshenqeeti, 2014). The second step was identification of consumer preference regarding seafood product attributes (i.e. product features, product functions, and product benefits) in quality dimensions (Garvin, 1987) using conjoint analysis for the target market (Lai, 1995). Within 
this step, the validity was measured by comparing how well conjoint utilities predicted choices from the holdout tasks (Orme, Alpert, \& Christensen, 1997). Consumers reflected the product attribute value for ensuring acceptability behavior and social intervention.

The third step was analysis of market identification and competition for simultaneous product benefits (i.e. shape, color, surface, texture, sanity, defect, solidness, nutrients, moisture, additives, chemicals, taste, aroma, flavor, physiological, social, psychological, safety, easiness, and affordability) that explain the prices. Regression analysis with the $2 \log$ likelihood model was used to see the significance of the observed variables (Iazzi, Vrontis, Trio, \& Melanthiou, 2016) performed with systemized, adapted, and statistical resources (Bergen \& Peteraf, 2002).

The best attributes from multivariate analysis with the Multidimensional Scaling (Verma, 2013) and the Correspondence Analysis (Kroonenberg \& Greenacre, 2004) were used to make a prompt decision of competitive positioning designs. Multidimensional Scaling/MDS and Correspondence Analysis/CA is a 20-item scale (i.e. shape, color, surface, texture, freshness, disabilities, density, nutritional value, moisture, additives, chemicals, flavor, aroma, taste, physiological function, social function, psychological function, food safety, ease of use, affordability) with reference to product features, product functions, and product benefits of quality dimensions. Multidimensional Scaling/MDS was rated on a 5point Likert scale, ranging from (1) very similar to (5) very different. Meanwhile, Correspondence Analysis/CA was rated on a 2-point Nominal scale, which were (0) the attributes are not satisfying and (1) the attributes are satisfied.

\section{RESULT AND DISCUSSIONS}

\section{The Consumer Characteristics}

Marketers need to understand the consumer characteristics that influence the buying behavior of seafood products as presented in Table 1 .

As seen in Table 1, most consumers were older adults, more experienced, and more interested in seafood products. Thus, consumer age affected their purchasing decisions (Drolet et al., 2010; Slabá, 2019). Since consumer behavior was a significant factor in product purchasing, religion also affected consumer values and actions in spending their money (Daas, 2018). Consumer ethnicity also impacted on a distinct pattern in buying behavior by informational influence and perception on the product attributes (Velioğlu, Karsu, \& Umut, 2013).

Family members were found to directly influence the purchase decision by justifying as well as highlighting the benefits of purchasing, forming coalitions, compromising, and remaining persistent in using their product-related knowledge and information to encourage parents to purchase certain products (Thomson, Laing, \& McKee, 2007; Polya \& Szucs, 2013). Meanwhile, education gave various perception on product values, such as functional, financial, individual, and social values. Thus, education was also an important demographic variable that affects the purchase decision (Srinivasan, Srivastava, \& Bhanot, 2014). 
TABLE 1. THE CONSUMERS' CHARACTERISTICS OF SEAFOOD PRODUCTS

\begin{tabular}{lclc}
\hline Characteristic & Percentage (\%) & Characteristic & Percentage (\%) \\
\hline Age (year): & & Education (year): & \\
$19-24$ & 5.34 & Less than 6 & 4.85 \\
$25-40$ & 31.55 & 6 & 4.85 \\
$40-49$ & 29.13 & 9 & 12.62 \\
More than 50 & 33.98 & 12 & 38.83 \\
Religion: & & More than 12 & 38.83 \\
Islam & 82.52 & Job-status: & \\
Christianity & 15.05 & Full-time & 14.08 \\
Buddhism & 2.43 & Part-time & 2.91 \\
Ethnicity: & & Student & 3.40 \\
Malay & 50.49 & Unemployment & 3.88 \\
Java & 17.48 & Retired & 22.33 \\
Dayak & 13.59 & Housewife & 53.40 \\
Bugis & 5.83 & Time of purchase: & \\
Others & 12.62 & Beginning of month & 60.68 \\
Family members: & & Middle of month & 16.99 \\
1 & 6.31 & End of month & 21.36 \\
2 & 7.28 & Expenditure (Rupiah): & \\
3 & 22.82 & Less than 279,800 & 90.78 \\
4 & 21.84 & 279,800 - less than 19,600 & 6.31 \\
5 & 29.61 & More than 419,600 & 6.31 \\
6 & 6.80 & & \\
7 & 4.85 & & \\
8 & 0.49 & & \\
\hline
\end{tabular}

Based on the job-status of the participants, most seafood product purchase decisions were made by the housewives as they often shopped in retail markets (Ahmed, Zamir, Yazdani, \& Mehmood, 2016) and chose types of products as well as food according to others' benefit experiences (Kumaravel, 2017) and psychological factors (Widodo, Rusimah, $\&$ Choirunisa, 2018). Time of purchase implies the level of decision-making time to anticipate regrets and achieve purchase satisfaction. Buying seafood products in the beginnings of the months reflects the perceived time of shopping situation (Moon \& Lee, 2013) due to the payday time. Last but not least, in the consumer expenditure, a certain amount of spending was influenced by the amount of income received, rational spending pattern, as well as socioeconomic and demographic factors (Mattila \& Wiro, 1999; Wilska, 2002).

\section{The Consumer Preference}

The second part was consumer preference of seafood products, which was defined as consumer purchase satisfaction. It reflects the product attribute value for ensuring acceptability behavior and social intervention, such as product features, functions (physiological, social, and psychological), and benefits as shown in Figure 1 and Figure 2.

In Figure 1, observed and estimated preferences have a very strong relationship. Product features was the most important dimension in consumer preference, followed by social function, product benefits, physiological function, and psychological function. These findings were in line with consumer characteristics. Age, religion, ethnicity, family members, education, job-status, time of purchase, and expenditure were significant factors in consumer 
values and actions, displaying a distinct pattern in buying behavior and perception on product attributes.

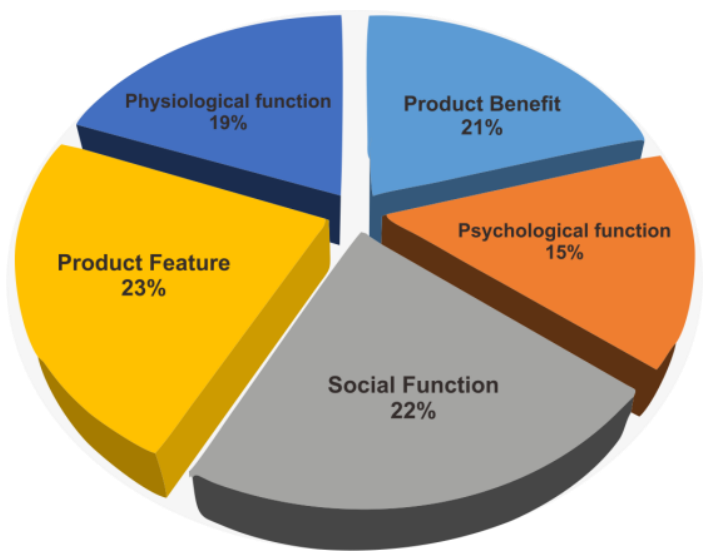

\section{FIGURE 1. THE ATTRIBUTE DIMENSIONS OF A PRODUCT FEATURES, FUNCTIONS, AND BENEFITS OF SEAFOOD PRODUCTS}

Product features affect buying satisfaction (Tanzila, Sohail, \& Tanveer, 2015) due to consumer emotional or cognitive knowledge of a particular experience at a particular time (Giese \& Cote, 2000). In addition, purchase satisfaction also gives the producer loyalty based on trust, perceived value, and positive emotional attachment (Rahmatiyah, Yulianto, \& Kusumawati, 2017; Scridon, Achim, Pintea, \& Gavriletea, 2019).

On the other hand, the social function provides a cognitive process of understanding the targeted communication with emotions (Bagozzi, Gopinath, \& Nyer, 1999). These emotions provide embodied information about the costs and benefits of an action which were assumed to explain some of the purchased items (Zadra \& Clore, 2011). The balance of positive and negative emotions will drive to consumer decision making (Soodan, $\mathrm{V}$. Pandey, 2016).

The product benefit dimension was the main key for sustaining the perceived values of utility, benefits, quality, and satisfaction in the market competition (Morar, 2013; Aulia et al., 2016). The higher perceived value level indicates the higher direct effect over the consumer repurchase intention (Hellier, Geursen, Carr, \& Rickard, 2003), loyalty (Ramadhan \& Siagian, 2019), and satisfaction (Raji \& Zaina, 2016).

Consumer characteristics considered as an active interpreters of marketing, so marketers have to look into both the consumer physiological and psychological character traits. These traits directly affect the need, the desire, and how stimuli are interpreted (Vainikka, 2015). In psychological attributes, consumers are bound to have cognitive, emotional, and behavioral predispositions (Park, MacInnis, \& Priester, 2007). The intensity of psychological attributes affects both consumers' negative and positive attitude responses and producers' advertising responses (Loken, 2006). The physiological attributes are those related to the physical body that affects the thinking and certain types of attitudes that predispose consumer preference (Lefcheck, Whalen, Davenport, Stone, \& Duffy, 2013; Vainikka, 2015). Each attribute of product features, physiological function, social function, psychological function, and benefit dimensions as shown in Figure 2. 
In Figure 2, negative and positive utility attributes reflect the decreasing and increasing pleasure of consumer preference. The negative attributes were referred to as the risks or negative impacts of the consumer purchase decision (Nguyen \& Gizaw, 2014). Figure 2 also shows the attributes that could not meet the priority of purchasing decision-making or deficiency to interact with what consumers think and act on (Zia, 2017).

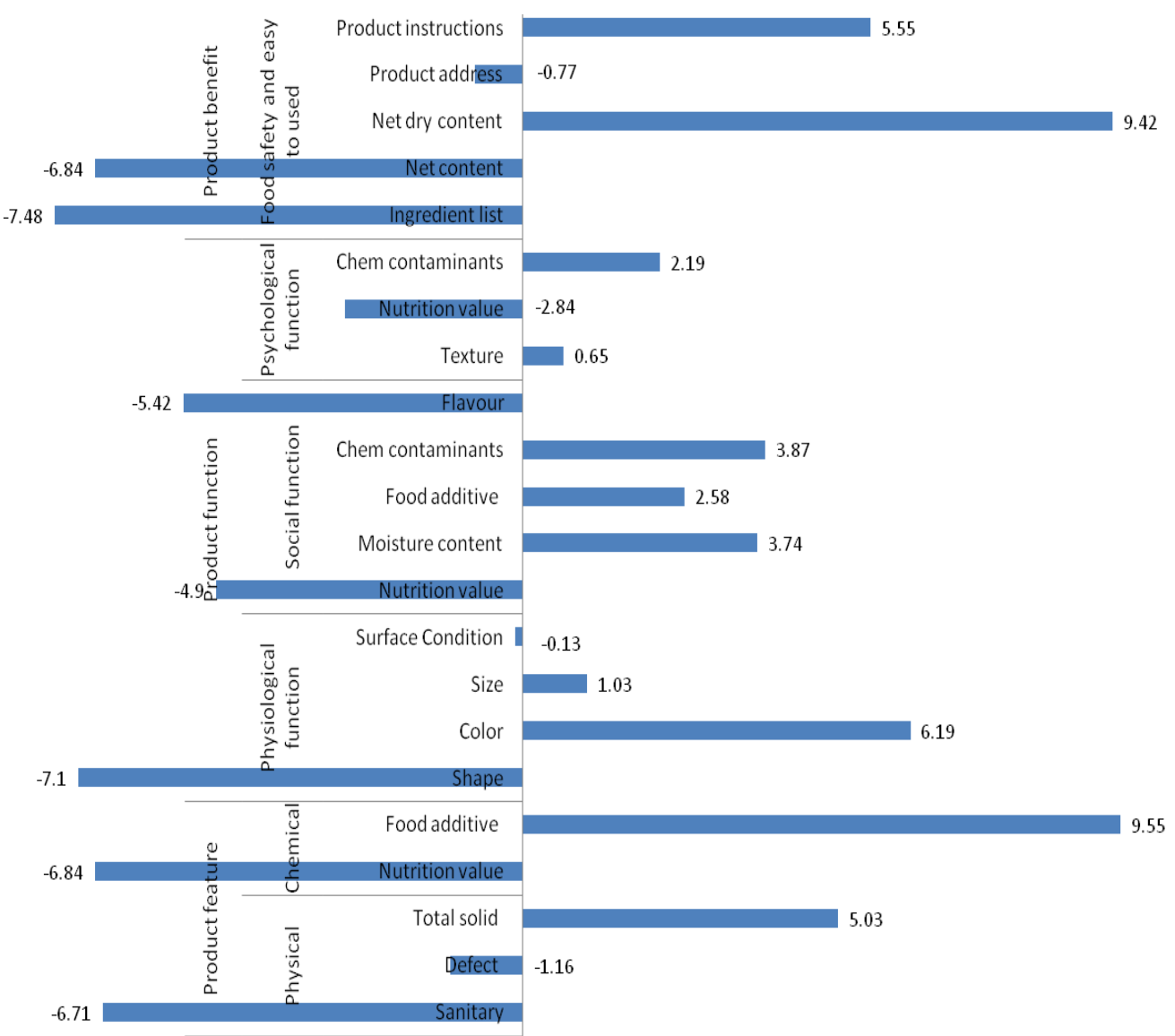

\section{FIGURE 2. THE PRODUCT UTILITY ATTRIBUTES OF FEATURE, PHYSIOLOGICAL FUNCTION, SOCIAL FUNCTION, PSYCHOLOGICAL FUNCTION, AND PRODUCT BENEFITS DIMENSIONS OF SEAFOOD PRODUCTS}

The attributes that most influence consumer preference were food additive (the chemicals in product features) and net dry content (food safety and easy-to-use feature in product benefits), followed by color (physiological aspect in product functions), product instruction (food safety and ease of use in product benefits), total solidness (physical aspect in product features), chemical content (social aspect in product functions), moisture content (social aspect in product functions), food additives (social aspect in product functions), chemical content (psychological aspect in product functions), size (physiological aspect in product features), and texture (psychological aspect in product functions).

The chemical content as food additives in the product features attracted potential consumers. The chemical taste enhancers (Thunström, 2009) improve the product quality and functionality, which are from seafood, plants, mushrooms, animal sources, and other functional materials (Bashir, Kim, An, Sohn, \& Choi, 2017). However, the use of chemical food additives should be conducted by considering food safety and including them in 
information label on the packaging (Tarnavölgyi, 2003; Sachithananthan, 2017). Net dry content in food safety and ease of use in product benefits are the dimensions that explain the consumers' reasons for purchasing the products by utilizing their cognitive processing based on prior knowledge that focuses on important information and health decisions (Miller \& Cassady, 2015).

In the physiological function, there was a strong relationship of colors with moods and behaviors (Küller, Ballal, Laike, Mikellides, \& Tonello, 2006; Kurt \& Osueke, 2014) due to the basic neurological stimulation as a form of specific brain responses (Valdez \& Mehrabian, 1994). Thus, marketers should be able to identify emotional benefits for a brand identity. At the same time, there were issues of food naturalness and authenticity in terms of food safety and easy-to-use feature in food distribution demanded by consumers (Yeung \& Morris, 2001; Fontes et al., 2015). The perception of healthy ingredients became a marketing strategy for restoring the purchase intention and mitigated the blame among consumers (Roy, Tata, \& Parsad, 2018).

In physical products, consumer preference on seafood products were solid (Loporcaro, Campo, \& Baldassarre, 2017). It was critical for producers, processors, and fishers to understand the food item physical properties in their jobs (Ward \& Beyens, 2012). Producers must be knowledgeable in force and deformation as they are fracturing the food mechanics (Vincent, 2004), in which the rheology of certain food products is (Schurz, 1967) when changing raw products into usable products.

Furthermore, consumers were concerned about chem-contaminated products because of other consumers' observation, objective information from the media, social networks, and past contamination (Frank \& Schvaneveldt, 2016). Changes in moisture content can affect a product's internal structures (Figueroa, Moraes, \& Maestri, 2015), as in the surface becomes rougher, getting more turgid, less crisp, and stiff (Hawaree, Chiewchan, \& Devahastin, 2009; Onwulata et al., 2013).

In food additive social function, consumers tended to have more positive attitudes and intentions toward fishery products due to sufficient information on food additives (Seo, Kim, \& Shim, 2014). Creating awareness and knowledge about food additives through the content information on the product package is one way to educate consumers about product contents (Sachithananthan, 2017). The avoidance of food additives is highly influenced by knowledge level (Szűcs, Szabó, Guerrero, Tarcea, \& Bánáti, 2019).

Consumers also expressed strong concerns about psychological chemical contents due to severe long-term consequences (Kher et al., 2013). Consumers considered traceability as a useful tool to improve consumer confidence in food safety (Zhang, Mankad, \& Ariyawardana, 2020). The physiological of size as part of product feature affected consumer decision due to sufficient resolution in capturing images of consumer acceptance and product success (Lautiainen, 2015). Therefore, it will help advertisers, producers, managers, and designers to make the most appropriate choice with potential benefits and effectiveness (Nurliza \& Dolorosa, 2017). 
Regarding texture, as part of psychological function, the positive hedonic response was associated with specific sensory cues. Consumers considered that sensory cues influence the way food tastes and textures, how it feels in the mouth, as well as the food rheological (Stokes et al., 2013; Pramudya \& Seo, 2019) through cutting, shearing, chewing, compressing, or stretching (Kohyama, 2020). However, consumers had less hedonic pleasure of ingredient list and net content (food safety and ease of use in product benefits); physiological aspect in product functions; nutrition value (psychological and social aspects in product functions); nutrition value (the chemicals in product feature), sanitary, and defect (physical aspect in product feature). Therefore, producers need to consider seafood products' shape and surface with innovative, attractive, as well as understandable ideas (Girard \& Payrat, 2017) and improve the texture for sensory cues but with a supportive environment (McCrickerd \& Forde, 2016).

\section{Market Identification and Competition Analysis}

Market identification and competition analyses for seafood products prove that all of the primary benefits of product characteristics are quite appropriate, and the price is appropriate and affordable for consumers as shown in Table 2.

TABLE 2. THE PRICE OF UNBUNDLED OR BUNDLED OFFERS COMPARES TO THE PRIMARY BENEFIT OF PRODUCT CHARACTERISTIICS

\begin{tabular}{|l|c|c|c|c|c|}
\hline \multirow{2}{*}{ Product characteristics } & \multicolumn{5}{|c|}{ Benefit Product characteristics } \\
\cline { 2 - 6 } & Very inappropriate & Inappropriate & Quite appropriate & Appropriate & Very appropriate \\
\hline Price (\%) & 5.56 & 55.56 & 18.18 & 7.07 & 13.64 \\
\hline Shape (\%) & & 7.07 & 25.25 & 58.59 & 9.09 \\
\hline Color (\%) & & 2.02 & 37.88 & 54.04 & 6.06 \\
\hline Surface condition (\%) & & 3.03 & 37.88 & 51.52 & 7.58 \\
\hline Texture (\%) & & 3.03 & 30.81 & 57.07 & 9.09 \\
\hline Sanity (\%) & & 9.09 & 28.79 & 55.56 & 6.57 \\
\hline Defect (\%) & & 20.20 & 22.22 & 39.39 & 18.18 \\
\hline Total Solid (\%) & & 8.59 & 40.91 & 40.91 & 9.60 \\
\hline Nutrition value (\%) & & 11.11 & 47.47 & 37.37 & 4.04 \\
\hline Moisture content (\%) & & 6.06 & 54.04 & 34.85 & 5.05 \\
\hline Food additive (\%) & & 16.16 & 54.55 & 23.23 & 6.06 \\
\hline Chem contaminants (\%) & & 23.74 & 40.91 & 28.79 & 6.57 \\
\hline Taste (\%) & & 1.01 & 29.29 & 58.08 & 11.62 \\
\hline Aroma (\%) & & 6.57 & 43.94 & 37.88 & 11.62 \\
\hline Flavor (\%) & 1.52 & 32.83 & 56.06 & 9.60 \\
\hline The physiological functions (\%) & & 10.10 & 47.47 & 39.90 & 2.53 \\
\hline The social function of food (\%) & & 20.71 & 46.46 & 25.76 & 7.07 \\
\hline The psychological functions of food (\%) & & 8.08 & 47.98 & 38.89 & 5.05 \\
\hline Food safety (\%) & 1 & 30.30 & 29.80 & 29.29 & 10.10 \\
\hline Easy to used (\%) & & & 23.23 & 59.60 & 17.17 \\
\hline Afffordability (\%) & & & 22.73 & 48.48 & 28.79 \\
\hline
\end{tabular}

The regression model analysis of the benefits of seafood products simultaneously explains the prices as shown in Table 3. 
The benefits of seafood product characteristics (nutrition in chemical benefits, the flavor in sensory benefits, and food safety) positively related to price. Consumers pay different primary levels of benefits or higher levels of each benefit (D'Aveni, 2007) but markets tended to cover at the same price because there was no distance and disparities of price benefits or no price deviation (Figure 3).

TABLE 3. THE REGRESSION OF THE PRICE-BENEFIT EQUATION

\begin{tabular}{|c|c|c|c|}
\hline \multicolumn{2}{|c|}{ Parameters } & \multirow{2}{*}{$\frac{\text { Estimate }}{-1.218(1.690)}$} & \multirow{2}{*}{$\begin{array}{r}\text { Wald } \\
.519\end{array}$} \\
\hline Threshold & {$[$ price $=1,00]$} & & \\
\hline & {$[$ price $=2,00]$} & 2.324 (1.689) & 1.894 \\
\hline & {$[$ price $=3,00]$} & 3.293 (1.697) & 3.768 \\
\hline & {$[$ price $=4,00]$} & 3.826 (1.702) & 5.050 \\
\hline \multirow[t]{20}{*}{ Location } & Shape & -.377 (.232) & 2.647 \\
\hline & Color & $-.128(.266)$ & .233 \\
\hline & Surface & $.406 \quad(.287)$ & 2.001 \\
\hline & Texture & $-.433(.277)$ & 2.447 \\
\hline & Sanity & $-.024(.222)$ & .012 \\
\hline & Defect & $-.115(.175)$ & .430 \\
\hline & Solid & $-.198 \quad(.226)$ & .768 \\
\hline & Nutrition & $.421 \quad(.240)$ & $3.088^{*}$ \\
\hline & Moisture & $-.241 \quad(.250)$ & .929 \\
\hline & Additive & $.052(.251)$ & .043 \\
\hline & Chem & $.318(.214)$ & 2.204 \\
\hline & Taste & $.322(.286)$ & 1.272 \\
\hline & Aroma & $-.055(.218)$ & .063 \\
\hline & Flavor & $-.509 \quad(.265)$ & 3.696 \\
\hline & Physiological & .138 (.263) & .276 \\
\hline & Social & $.014(.198)$ & .005 \\
\hline & Psychological & $.166(.249)$ & .445 \\
\hline & Food safety & $.279(.168)$ & $2.768^{*}$ \\
\hline & Easy & $.320(.293)$ & 1.190 \\
\hline & Affordability & $.215 \quad(.235)$ & .833 \\
\hline
\end{tabular}

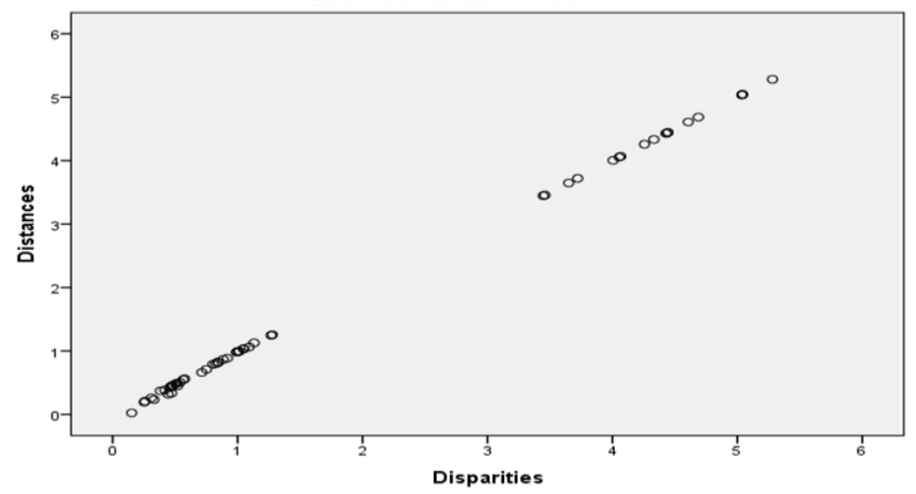

FIGURE 3. THE CONSISTENCY TEST OF THE RESPONDENT'S ATIITUDE

Dimensions of seafood products for market identification and competition illustrated in Figure 4, as well as respondents' attitude toward product feature attributes (the first dimension), product function attribute dimension (the second dimension), and product accessibility attribute dimension (the third dimension). Products in the same dimension 
competed with each other, while products in different dimensions were complement or independent.

In Figure 4, shredded fish, shrimp paste, surimi, canned fish, crackers, salted fish, cencalok, empek-empek, and presto competed in product feature attributes. While botok and curry competed in product function. However, all the seafood products were complements or independent in product accessibility.

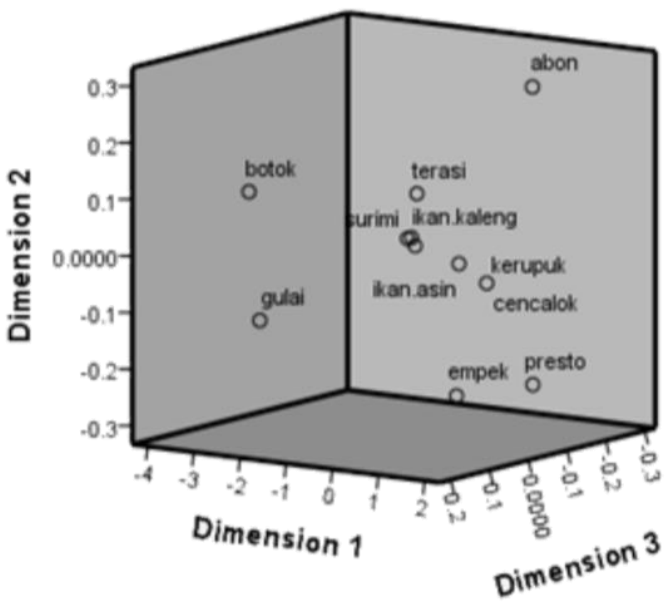

FIGURE 4. DIMENSIONS OF SEAFOOD PRODUCTS FOR MARKET IDENTIFICATION AND COMPETITION

\section{Perceptual Mapping for Competitive Positioning}

The relative perceived strengths and weaknesses prove that mostly, seafood product attributes have the same level of similarity and satisfaction as shown in Table 4.

TABIE 4. SIMILIARITY AND SATISFACTION LEVEL OF FISHERY PRODUCTS ATIBUUTES

\begin{tabular}{|l|c|c|c|c|c|c|c|}
\hline \multirow{2}{*}{ Attributes } & \multicolumn{3}{|c|}{ Level of Similiarity } & \multicolumn{2}{c|}{ Level of Satisfaction } \\
\cline { 2 - 8 } & Very similar & Similar & Quite similar & Different & Very different & Unsatisfied & Satisfied \\
\hline Shape (\%) & 16.90 & 42.57 & 24.24 & 14.86 & 1.43 & 12.63 & 87.37 \\
\hline Color (\%) & 15.07 & 40.73 & 26.48 & 15.68 & 2.04 & 12.58 & 87.42 \\
\hline Surface condition (\%) & 16.33 & 48.75 & 31.41 & 1.21 & 2.30 & 12.09 & 87.91 \\
\hline Texture (\%) & 19.59 & 38.57 & 30.01 & 10.20 & 1.63 & 9.83 & 90.17 \\
\hline Sanity (\%) & 14.49 & 35.71 & 36.53 & 11.84 & 1.43 & 12.6 & 87.4 \\
\hline Defect (\%) & 12.37 & 33.20 & 34.85 & 17.11 & 2.47 & 9.83 & 90.17 \\
\hline Total Solid (\%) & 18.00 & 35.17 & 33.13 & 12.88 & 0.82 & 21.69 & 78.31 \\
\hline Nutrition value (\%) & 12.50 & 40.98 & 35.25 & 9.43 & 1.84 & 27.50 & 72.50 \\
\hline Moisture content (\%) & 14.00 & 41.00 & 36.00 & 8.00 & 1.00 & 14.52 & 85.48 \\
\hline Food additive (\%) & 12.00 & 46.00 & 31.00 & 8.00 & 3.00 & 24.38 & 75.62 \\
\hline Chem contaminants (\%) & 15.00 & 0 & 54.00 & 26.00 & 5.00 & 24.38 & 75.62 \\
\hline Taste (\%) & 10.00 & 38.00 & 36.00 & 14.00 & 2.00 & 13.35 & 86.65 \\
\hline Aroma (\%) & 9.00 & 37.00 & 36.00 & 15.00 & 3.00 & 17.00 & 83.00 \\
\hline Flavor (\%) & 11.00 & 35.00 & 36.00 & 16.00 & 2.00 & 17.00 & 83.00 \\
\hline The physiological functions (\%) & 14.00 & 32.00 & 46.00 & 6.00 & 2.00 & 34.00 & 66.00 \\
\hline The social function of food (\%) & 20.00 & 40.00 & 32.00 & 8.00 & 0 & 13.00 & 87.00 \\
\hline The psychological functions of food (\%) & 20.30 & 36.70 & 33.10 & 9.20 & 0.60 & 36.00 & 64.00 \\
\hline Food safety (\%) & 21.00 & 47,50 & 22.05 & 4.95 & 4.05 & 31.00 & 69.00 \\
\hline Easy to used (\%) & 20.70 & 45.30 & 24.00 & 8.00 & 1.80 & 6.00 & 94.00 \\
\hline Affordability & 23.69 & 39.83 & 22.64 & 10.90 & 2.93 & 17.00 & 83.00 \\
\hline
\end{tabular}


Meanwhile, customer satisfaction levels on the attributes of seafood products show some similarities (Figure 5), which was in line with the results of consumer perception in the perceptual distribution (Figure 6).

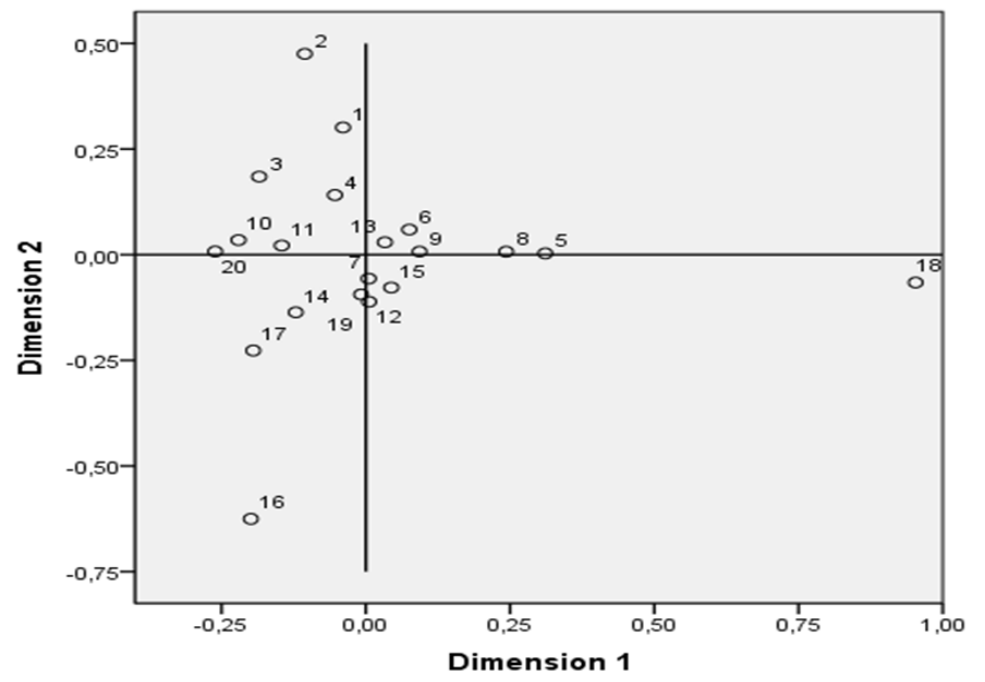

FIGURE 5. PERCEPTUAL SIMILIARITIES OF FISHERY PRODUCTS ATTRIBUTES

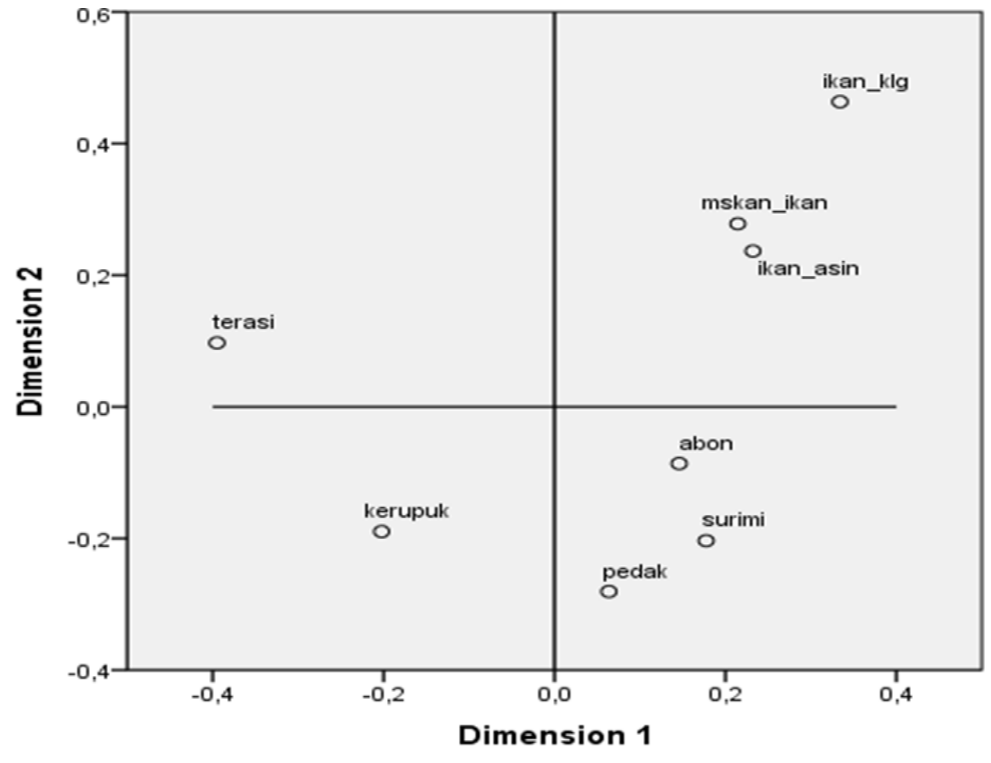

FIGURE 6. PERCEPTUAL DISTRIBUTION OF SEAFOOD PRODUCTS

It showed that canned fish, dried fish, and salted fish provide similar satisfaction. Shredded fish, surimi, and pedak also provide similar satisfaction. However, the shrimp paste and crackers provide different satisfaction in their distribution, which leads to a willingness to pay (WTP) at higher prices, while perceived risk influences behavioral intention (Demirgüneş, 2015). The perceptual distribution combination of seafood product attributes as shown in Figure 7.

In Figure 7, the groups of seafood product attribute with similar satisfaction: (i) pedak, crackers, shrimp paste, and salted fish; and (ii) surimi, dried fish, shrimp paste, shredded fish, and canned fish. These findings illustrate that the group of pedak, crackers, shrimp paste, and salted fish can compete with the group of surimi, dried fish, shrimp paste, shredded fish, and canned fish. Meanwhile, the best attributes of seafood products is presented in Table 5. 


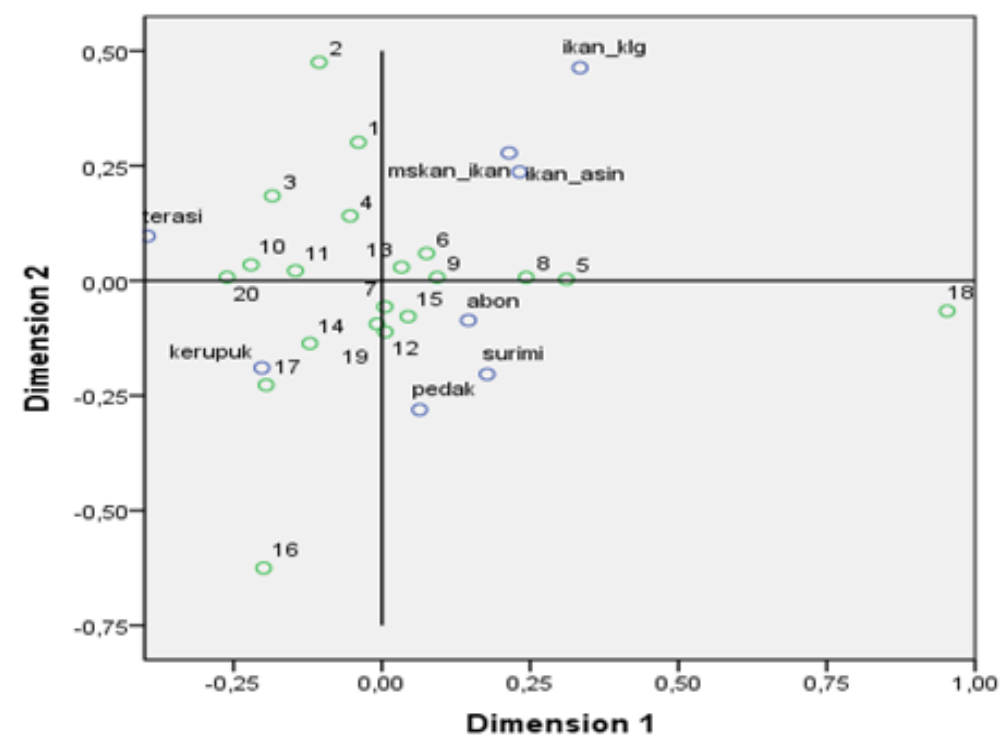

FIGURE 7. PERCEPTUAL DISTRIBUTION COMBINATION OF SEAFOOD PRODUCT ATTRIBUTES

TABLE 5. THE BEST ATTRIBUTES OF SEAFOOD PRODUCTS

\begin{tabular}{ll}
\hline Seafood products & \multicolumn{1}{c}{ The best attributes } \\
\hline canned fish, dried fish, and salted fish & freshness, durability, nutritional value, moisture content, and \\
& food safety through labels $(5,6,8,9,18)$ \\
\hline shredded fish, surimi, and pedak & density, nutritional value, moisture content, taste, physiological \\
& function, and easy-to-use feature $(7,8,9,12,15,19)$ \\
\hline cracker's & taste, social function, psychological function, and affordability \\
& $(14,16,17,20)$ \\
\hline shrimp paste & shape, color, sufface condition, texture, additive content, \\
& chemical, and affordability $(1,2,3,4,10,11,20)$ \\
\hline
\end{tabular}

There is no need to compete with each other in the similar perception of seafood products. In Table 2, group of seafood product can compete to each other by using their best attributes. The group of canned fish, dried fish, and salted fish can use the attribute of freshness, durability, and food safety through labels by being transported and packed to processing plants (Song, Moon, Chen, \& Houston, 2018) and food storage facilities (Nagar, 2007). Meanwhile, group of shredded fish, surimi, and pedak can use attribute of density, taste, physiological function, and easy-to-use feature by increasing food diversity, food fortification, and supplementation (Smith, Coffin, Miller, \& Popper, 2006).

Crackers can use attribute of taste, social function, and psychological function by using cultural congruence between the product and the market (Song et al., 2018) with certain packaging design, launch timing, and advertising. On the other hand, shrimp paste can use attribute of shape, color, surface condition, texture, additive content, and chemicals by using pasteurized before packaging, natural food additives, quick freezing, retort pouch, and cook-chilling (Venugopal, 2005).

These findings gave the ways to treat seafood products with similar and different satisfactions for customer loyalty, extend the life cycle of a customer, expand the life of merchandise the customer purchase, and deliver positive words by direct communication (Ruzzier, Ruzzier, \& Hisrich, 2013). They will help make a prompt decision for the 
continuous improvement of the business or management approaches about customer expectation. Thus, stakeholders can use these seafood product best attributes to formulate competitive positioning in marketing strategy and communication to ensure consumer satisfaction and producer profit.

\section{CONCLUSION}

Product features was the most important dimension in consumer preference that was in line with consumer characteristics. Food additive and net dry content are the most attributes that influence consumer preference, while the benefits of seafood product characteristics positively related to price. The findings proved canned fish, dried fish, and salted fish competed on freshness, durability, and food safety (labels). Shredded fish, surimi, and pedak competed on density, taste, physiological function, and easy-to-use feature by increasing food diversity, fortification, and supplementation. Crackers competed on taste, social function, and psychological function. Shrimp paste competed on shape, color, surface condition, texture, additive content, and chemicals. Thus, there were concerns in marketing strategy and communication to ensure consumer satisfaction and producer profit, such as transporting and packing to processing plants and food storage facilities. Besides, it was necessary to increase food diversity, food fortification, and supplementation. Certain packaging designs, launch timing, and advertising were needed in cultural congruence between the product and the market. Pasteurization was needed before packaging, as well as natural food additives, quick freezing, retort pouch, and cook-chilling.

\section{ACKNOWLEDGMENT}

We would like to express sincere gratitude to the Faculty of Agriculture, University of Tanjungpura for funding the research.

\section{REFERENCES}

Ahmed, R. R., Zamir, M., Yazdani, S., \& Mehmood, S. (2016). Factors Impacting the Buying Behavior of Housewives towards Hypermarkets in Karachi. Journal of Marketing and Consumer Research, 19, 6-12.

Alfnes, F., Chen, X., \& Rickertsen, K. (2018). Labeling Farmed Seafood: A Review. Aquaculture Economics $\mathcal{E} \quad$ Management, $22(1), \quad 1-26$. https://doi.org/10.1080/13657305.2017.1356398

Alshenqeeti, H. (2014). Interviewing as a Data Collection Method: A Critical Review. English Linguistics Research, 3(1), 39-45. https://doi.org/10.5430/elr.v3n1p39

Aulia, S. A., Sukati, I., \& Sulaiman, Z. (2016). A Review: Customer Perceived Value and its Dimension. Asian Journal of Social Sciences and Management Studies, 3(2), 150-162. https://doi.org/10.20448/journal.500/2016.3.2/500.2.150.162

Bagozzi, R. P., Gopinath, M., \& Nyer, P. U. (1999). The Role of Emotions in Marketing. Journal of the Academy of Marketing Science, 27(2), 184-206. https://doi.org/10.1177/0092070399272005 
Bashir, K. M. I., Kim, J.-S., An, J. H., Sohn, J. H., \& Choi, J.-S. (2017). Natural Food Additives and Preservatives for Fish-Paste Products: A Review of the Past, Present, and Future States of Research. Journal of Food Quality, 2017, 1-31. https://doi.org/10.1155/2017/9675469

Bergen, M., \& Peteraf, M. A. (2002). Competitor identification and competitor analysis: a broad-based managerial approach. Managerial and Decision Economics, 23(4-5), 157169. https://doi.org/10.1002/mde.1059

Cohen, L., Manion, L., \& Morrison, K. (2017). The Ethics of Educational and Social Research. In Research Methods in Education (pp. 111-143). New York: Routledge. https://doi.org/10.4324/9781315456539-7

D'Aveni, R. A. (1998). Waking up to the new era of hypercompetition. The Washington Quarterly, 21(1), 183-195. https://doi.org/10.1080/01636609809550302

D’Aveni, R. A. (2007). Mapping Your Competitive Position. Harvard Business Review. https://hbr.org/2007/11/mapping-your-competitive-position

Daas, Y. (2018). How religion affects consumer behavior. Consumer attitudes and seasonal demand for products. Munich: GRIN Verlag, https://www.grin.com/document/492188

Demirgüneş B. K. (2015). Relative Importance of Perceived Value, Satisfaction and Perceived Risk on Willingness to Pay More. International Review of Management and Marketing, 5(4), 211-220.

Drolet, A., Schwarz, N., \& Yoon, C. (2010). The Aging Consumer: Perspectives From Psychology and Economics. (A. Drolet, C. Yoon, \& C. Yoon, Eds.). Routledge. https://doi.org/10.4324/9780203852941

Engle, C. R., Quagrainie, K. K., \& Dey, M. M. (2016). Seafood demand analysis. In Seafood and Aquaculture Marketing Handbook (pp. 293-329). Chichester, UK: John Wiley \& Sons, Ltd. https://doi.org/10.1002/9781118859223.ch11

FAO. (2013). Lessons learned note: Improving the quality of fishery products and market chains. Retrieved from http://www.fao.org/publications/card/en/c/7047c8fc-f9ac-458b-98afa56722fce 173

Figueroa, M. J. M., Moraes, P. D. de, \& Maestri, F. A. (2015). Temperature and Moisture Content Effects on Compressive Strength Parallel to The Grain of Paricá. Ambiente Construido, 15(1), 17-27. https://doi.org/10.1590/S1678-86212015000100003

Fontes, M. A., Giraud-Héraud, E., \& Pinto, A. S. (2015). Consumers' Behaviour Towards Food Safety: A Literature Review. In Food Safety, Market Organization, Trade and Development (pp. 111-131). Cham: Springer International Publishing. https://doi.org/10.1007/978-3-319-15227-1_6

Frank, B., \& Schvaneveldt, S. J. (2016). Understanding Consumer Reactions to Product Contamination Risks After National Disasters: The Roles of Knowledge, Experience, and Information Sources. Journal of Retailing and Consumer Services, 28, 199-208. https://doi.org/10.1016/j.jretconser.2015.08.005

Garvin, D. A. (1987). Competing on the Eight Dimensions of Quality. Harvard Business Review. https://hbr.org/1987/11/competing-on-the-eight-dimensions-of-quality 
Giese, J., \& Cote, J. (2000). Defining Consumer Satisfaction. Academy of Marketing Science Review, 4(January), 1-24.

Girard, P., \& Payrat, T. Du. (2017). An inventory of New Technologies in Fisheries: Challenges and opportunities in using new technologies to monitor Sustainable fisheries. Paris: OECD Green Growth and Sustainable Development Forum.

Hawaree, N., Chiewchan, N., \& Devahastin, S. (2009). Effects of Drying Temperature and Surface Characteristics of Vegetable on the Survival of Salmonella. Journal of Food Science, 74(1), E16-E22. https://doi.org/10.1111/j.1750-3841.2008.01010.x

Hellier, P. K., Geursen, G. M., Carr, R. A., \& Rickard, J. A. (2003). Customer Repurchase Intention: A General Structural Equation Model. European Journal of Marketing, 37(11/12), 1762-1800. https://doi.org/10.1108/03090560310495456

Hunt, S. D., \& Arnett, D. B. (2004). Market Segmentation Strategy, Competitive Advantage, and Public Policy: Grounding Segmentation Strategy in ResourceAdvantage Theory. Australasian Marketing Journal, 12(1), 7-25. https://doi.org/10.1016/S1441-3582(04)70083-X

Iazzi, A., Vrontis, D., Trio, O., \& Melanthiou, Y. (2016). Consumer preference, satisfaction, and intentional behavior: Investigating consumer attitudes for branded or unbranded products. Journal of Transnational Management, 21(2), 84-98. https://doi.org/10.1080/15475778.2016.1167000

Ingleby, E. (2012). Research methods in education. Professional Development in Education, 38(3), 507-509. https://doi.org/10.1080/19415257.2011.643130

Kher, S. V., De Jonge, J., Wentholt, M. T. A., Deliza, R., de Andrade, J. C., Cnossen, H. J., ... Frewer, L. J. (2013). Consumer Perceptions of Risks of Chemical and Microbiological Contaminants Associated with Food Chains: A Cross-National Study. International Journal of Consumer Studies, 37(1), 73-83. https://doi.org/10.1111/j.14706431.2011.01054.x

Kohyama, K. (2020). Food Texture - Sensory Evaluation and Instrumental Measurement. In K. Nishinari (Ed.), Textural Characteristics of World Foods (pp. 1-13). Wiley. https://doi.org/10.1002/9781119430902.ch1

Kroonenberg, P. M., \& Greenacre, M. J. (2004). Correspondence Analysis. In Encyclopedia of Statistical Sciences. Hoboken, NJ, USA: John Wiley \& Sons, Inc. https://doi.org/10.1002/0471667196.ess6018

Küller, R., Ballal, S., Laike, T., Mikellides, B., \& Tonello, G. (2006). The Impact of Light and Colour on Psychological Mood: A Cross-Cultural Study of Indoor Work Environments. Ergonomics, 49(14), 1496-1507. https://doi.org/10.1080/00140130600858142

Kumaravel, R. (2017). Consumer Shopping Behaviour and The Role of Women in Shopping-A Literature Review. Research Journal of Social Science and Management, 7(December), 50-63. Retrieved from www.theinternationaljournal.org

Kurt, S., \& Osueke, K. K. (2014). The Effects of Color on the Moods of College Students. SAGE Open, 4(1). https://doi.org/10.1177/2158244014525423 
Lai, A. W. (1995). Consumer Values, Product Benefits and Customer Value: a Consumption Behavior Approach. In F. R. Kardes \& M. Sujan (Eds.), Advances in Consumer Research Volume 22 (pp. 381-388). Provo: UT: Association for Consumer Research. Retrieved from https://www.acrwebsite.org/volumes/7772/volumes/v22/NA-22

Lautiainen, T. (2015). Factors affecting consumers' buying decision in the selection of a coffee brand. Retrieved from https://www.semanticscholar.org/paper/Factorsaffecting-consumers\%27-buying-decision-in-the-

Lautiainen/b9a34eb78e492a915eb296f2661656cc0cd1406b

Lefcheck, J. S., Whalen, M. A., Davenport, T. M., Stone, J. P., \& Duffy, J. E. (2013). Physiological Effects of Diet Mixing on Consumer Fitness: A Meta-Analysis. Ecology, 94(3), 565-572. https://doi.org/10.1890/12-0192.1

Loken, B. (2006). Consumer Psychology: Categorization, Inferences, Affect, and Persuasion. Annual Review of Psychology, 57, 453-485. https://doi.org/10.1146/annurev.psych.57.102904.190136

Loporcaro, G., Campo, R., \& Baldassarre, F. (2017). The Effect of Food Aesthetics on Consumers. Visual Stimuli and Food Marketing. DIEM: Dubrownik International Economic Meeting. https://www.semanticscholar.org/paper/THE-EFFECTS-OFFOOD-AESTHETICS-ON-CONSUMERS.-VISUAL-CampoLoporcaro/605f70c7c2079e19dcefe5c8366b42f36f7c3285

Mattila, P., \& Wiro. (1999). Economic Theories of the Household: A Critical Review (UNU World Institue for Development Economics Research (UNU/WIDER) No. 159). Helsinki. Retrieved from https://www.wider.unu.edu/sites/default/files/wp159.pdf

McCrickerd, K., \& Forde, C. G. (2016). Sensory Influences on Food Intake Control: Moving Beyond Palatability. Obesity Reviews, 17(1), 18-29. https://doi.org/10.1111/obr.12340

Miller, L. M. S., \& Cassady, D. L. (2015). The Effects of Nutrition Knowledge on Food Label Use. A Review of The Literature. Appetite, 92, 207-216. https://doi.org/10.1016/j.appet.2015.05.029

Moon, J.-Y., \& Lee, K.-H. (2013). Influence of Time Pressure on the Purchase Decision Making Process in Apparel Shopping. The Research Journal of the Costume Culture, 21(1), 117-128. https://doi.org/10.7741/rjcc.2013.21.1.117

Morar, D. D. (2013). An Overview of The Consumer Value Literature - Perceived Value, Desired Value. In 6th Edition of the International Conference "Marketing - from information to decision" (pp. 169-186).

Nagar, D. P. (2007). Food Storage Strategies in Plants and Animals. Invention Intelegence, 42, 43-44.

Nguyen, T. H., \& Gizaw, A. (2014). Factors that influence consumer purchasing decisions of Private Label Food Products A case study of ICA Basic. School of Business, Society and Engineering.

Nurliza, N., \& Dolorosa, E. (2017). Quality Dimensions of Purchase Behavior Decision on Fishery Products. Jurnal Manajemen Dan Agribisnis, 14(2), 79-91. https://doi.org/10.17358/jma.14.2.79 
OECD-FAO. (2018). Chapter 8. Fish and seafood. OECD/FAO Agricultural Outlook 2018-2027. Retrieved from http://www.fao.org/docrep/i9166e/i9166e_Chapter8_Fish_seafood.pdf

Olsen, S. O., Tuu, H. H., \& Grunert, K. G. (2017). Attribute importance segmentation of Norwegian seafood consumers: The inclusion of salient packaging attributes. Appetite, 117, 214-223. https://doi.org/10.1016/j.appet.2017.06.028

Onwulata, C. I., Pimentel, M. R., Thomas, A. E., Phillips, J. G., Tunick, M. H., Mukhopadhyay, S., ... Cooke, P. H. (2013). Instrumental Textural Perception of Food and Comparative Biomaterials. International Journal of Food Properties, 16(4), 928-948. https://doi.org/10.1080/10942912.2011.570469

Orme, B. K., Alpert, M. I., \& Christensen, E. (1997). Assessing the validity of conjoint analysiscontinued. Sawtooth Software Research Paper Series (Vol. 98382). Retrieved from https://www.sawtoothsoftware.com/download/techpap/assess2.pdf (accessed 5 July 2019)

Ostasevičiute, R., \& Šliburyte, L. (2008). Theoretical Aspects of Product Positioning in The Market. Engineering Economics, 56, 97-103. https://doi.org/10.5755/j01.ee.56.1.11665

Park, C. W., MacInnis, D. J., \& Priester, J. R. (2007). Beyond Attitudes: Attachment and Consumer Behavior. Seoul National Journal, 12(2), 3-36.

Polya, E., \& Szucs, R. S. (2013). Examining The Role of Family Members in Family Buying Center in Adult Hungarian Population. European Scientific Journal, 9(19), 1-8.

Pramudya, R. C., \& Seo, H. (2019). Hand-Feel Touch Cues and Their Influences on Consumer Perception and Behavior with Respect to Food Products: A Review. Foods, 8(7), 259. https://doi.org/10.3390/foods8070259

Rahmatiyah, R., Yulianto, E., \& Kusumawati, A. (2017). SATISFACTION, TRUST AND ATTACHMENT ON BRAND COMMUNITY CONTEXT: LOYALTY IMPACT. Russian Journal of Agricultural and Socio-Economic Sciences, 64(4), 133-138. https://doi.org/10.18551/rjoas.2017-04.18

Raji, M. N. A., \& Zaina, A. (2016). The Effect of Sustomer Perceived Value on Customer Satisfaction: A Case Study of Malay Upscale Restaurants. Geografia - Malaysian Journal of Society and Space, 12(3), 58-68.

Ramadhan, L., \& Siagian, Y. M. (2019). Impact of Customer Perceived Value on Loyalty: In Context Crm. Journal of Research in Business and Management, 7(3), 24-29. https://doi.org/10.31227/osf.io/mu6fb

Richards, L. (2015). How Effective Communication Will Help An Organization. Smallbusiness.Chron.Com.

Roy, V., Tata, S. V., \& Parsad, C. (2018). Consumer response to brand involved in food safety scandal: An exploratory study based on a recent scandal in India. Journal of Consumer Behaviour, 17(1), 25-33. https://doi.org/10.1002/cb.1666

Ruzzier, M. K., Ruzzier, M., \& Hisrich, R. D. (2013). Value, satisfaction and customer loyalty. In Marketing for Entrepreneurs and SMEs (pp. 21-36). Edward Elgar Publishing. https://doi.org/10.4337/9781781955970.00008

Sachithananthan, V. (2017). A Study onThe Consumer Awareness of Food Additives in Packaged Food and Their Effects on Health in Abha Region, Saudi Arabia. Journal of 
Food Technology and Preservation, 1(3), 14-27.

Saqib, N. (2019). A Positioning Strategy for A Tourist Destination, Based on Analysis of Customers' Perceptions and Satisfactions. Journal of Tourism Analysis: Revista de Análisis Turistico, 26(2), 131-151. https://doi.org/10.1108/JTA-05-2019-0019

Schurz, J. (1967). Rheological Methods. In M. J. R. CANTOW (Ed.), Polymer Fractionation (pp. 317-339). Elsevier. https://doi.org/10.1016/B978-1-4832-3245-4.50016-9

Scridon, M. A., Achim, S. A., Pintea, M. O., \& Gavriletea, M. D. (2019). Risk and Perceived Value: Antecedents of Customer Satisfaction and Loyalty in A Sustainable Business model. Economic Research-Ekonomska Istraživanja, 32(1), 909-924. https://doi.org/10.1080/1331677X.2019.1584043

Seo, S., Kim, O. Y., \& Shim, S. (2014). Using The Theory of Planned Behavior to Determine Factors Influencing Processed Foods Consumption Behavior. Nutrition Research and Practice, 8(3), 327-335. https://doi.org/10.4162/nrp.2014.8.3.327

Slabá, M. (2019). The impact of age on the customers buying behaviour and attitude to price. Littera Scripta, 12(2).

Smith, M. E., Coffin, A. B., Miller, D. L., \& Popper, A. N. (2006). Anatomical and Functional Recovery of the goldfish ( Carassius auratus ) ear following noise exposure. Journal of Experimental Biology, 209(21), 4193-4202. https://doi.org/10.1242/jeb.02490

Song, R., Moon, S., Chen, H., \& Houston, M. B. (2018). When Marketing Strategy Meets Culture: The Role of Culture in Product Evaluations. Journal of the Academy of Marketing Science, 46, 384-402. https://doi.org/10.1007/s11747-017-0525-x

Soodan, V. Pandey, A. C. (2016). Influence of Emotions on Consumer Behaviour: A Study on FMCG Purchases in Uttarkhand, India. Journal of Entrepreneurship, Business and Economics, 4(2), 163-181.

Srinivasan, R., Srivastava, R. K., \& Bhanot, S. (2014). Impact of education on purchase behaviour of luxury brands. IOSR Journal of Business and Management, 16(11), 63-74. https://doi.org/10.9790/487X-161116374

Stokes, J. R., Boehm, M. W., \& Baier, S. K. (2013). Oral Processing, Texture and Mouthfeel: From Rheology to Tribology and Beyond. Current Opinion in Colloid $\mathfrak{E}$ Interface Science, 18(4), 349-359. https://doi.org/10.1016/j.cocis.2013.04.010

Szűcs, V., Szabó, E., Guerrero, L., Tarcea, M., \& Bánáti, D. (2019). Modelling of Avoidance of Food Additives: A Cross Country Study. International Journal of Food Sciences and Nutrition, 70(8), 1020-1032. https://doi.org/10.1080/09637486.2019.1597837

Tanzila, Sohail, A. A., \& Tanveer, N. (2015). Buying Behavior of Smartphone among University Students in Pakistan. The International Journal of Business and Management, 3(1), 34-40.

Tarnavölgyi, G. (2003). Analysis of Consumers' Attitudes towards Food Additives Using Focus Group Survey. Agriculturae Conspectus Scientificus (ACS), 68(3), 193-196.

The David and Lucile Packard Foundation. (2017). Global Seadood Markets Strategy 2017-2022. Retrieved from https://www.packard.org/wp-content/uploads/2017/02/Global-SeafoodMarkets-Strategy-2017-2022-EXTERNAL.pdf 
Thomson, E. S., Laing, A. W., \& McKee, L. (2007). Family purchase decision making: exploring child influence behaviour. Journal of Consumer Behaviour, 6(4), 182-202. https://doi.org/https://doi.org/10.1002/cb.220

Thunström, L. (2009). Consumer Values of Health-Related Food Symbols and Chemical Food Additives - The Case of Breakfast Cereals (HUI Working Papers No. 25). Retrieved from https://ideas.repec.org/p/hhs/huiwps/0025.html

Vainikka, B. (2015). Psychological Factors Influencing Consumer Behaviour. Centria University of Applied Science. Retrieved from

https://www.theseus.fi/bitstream/handle/10024/96405/Vainikka_Bianca.pdf.pdf?seq uence $=1 \&$ is Allowed $=y$

Valdez, P., \& Mehrabian, A. (1994). Effects of Color on Emotions. Journal of Experimental Psychology: General, 123(4), 394-409. https://doi.org/10.1037/0096-3445.123.4.394

Velioğlu, M. N., Karsu, S., \& Umut, M. Ö. (2013). Purchasing Behaviors of the Consumers Based on Ethnic Identities in Turkey. Journal of Management and Marketing Research, 13(January).

Venugopal, V. (Ed.). (2005). Seafood Processing Adding Value Through Quick Freezing, Retortable Packaging and Cook-Chilling (1st Ed.). Boca Raton: CRC Press. https://doi.org/10.1201/9781420027396

Verma, J. P. (2013). Multidimensional Scaling for Product Positioning. In Data Analysis in Management with SPSS Software (pp. 443-460). India: Springer India. https://doi.org/10.1007/978-81-322-0786-3_14

Vincent, J. F. . (2004). Application of Fracture Mechanics to The texture of Food. Engineering Failure Analysis, 11(5), 695-704. https://doi.org/10.1016/j.engfailanal.2003.11.003

Ward, A., \& Beyens, Y. (2012). Fish Handling, Quality and Processing: Training and Community Trainers Manual (SmartFish Working Papers No. 001). Retrieved from http://www.fao.org/3/az083e/az083e.pdf

Widodo, W., Rusimah, S. Y., \& Choirunisa, N. (2018). Factors Affecting to Consumers' Attitude towards Halal Label on Nugget and Sausage Packaging: A Case Study on Housewives at One Residential in Yogyakarta City. AGRARIS: Journal of Agribusiness and Rural Development Research, 4(1), 36-43. https://doi.org/10.18196/agr.4158

Wilska, T.-A. (2002). Me - A Consumer? Consumption, Identities and Lifestyles in Today's Finland. Acta Sociologica, 45(3), 195-210. https://doi.org/10.1080/00016990260257184

Yeung, R. M. W., \& Morris, J. (2001). Food Safety Risk: Consumer Perception and Purchase Behaviour. British Food Journal, 103(3), 170-187. https://doi.org/10.1108/00070700110386728

Zadra, J. R., \& Clore, G. L. (2011). Emotion and Perception: The Role of Affective Information. Wiley Interdisciplinary Reviews: Cognitive Science, 2(6), 676-685. https://doi.org/10.1002/wcs. 147 
Zhang, A., Mankad, A., \& Ariyawardana, A. (2020). Establishing Confidence in Food Safety: Is Traceability A Solution in Consumers' Eyes? Journal of Consumer Protection and Food Safety, 15, 99-107. https://doi.org/10.1007/s00003-020-01277-y

Zia, M. (2017). Impact of Product Attributes on Purchase Decision: A Study of Processed Food Consumer in India. In The 10th Multidisciplinary Academic Conference (pp. 4251). Prague. 